\title{
Near surface geophysics techniques and geomorphological approach to reconstruct the hazard cave map in historical and urban areas
}

\author{
M. Lazzari, A. Loperte, and A. Perrone \\ CNR-IBAM C/da S.Loja Zona Industriale Tito Scalo (PZ) 85050, Italy \\ Received: 24 October 2009 - Revised: 3 January 2010 - Accepted: 2 February 2010 - Published: 16 March 2010
}

\begin{abstract}
This work, carried out with an integrated methodological approach, focuses on the use of near surface geophysics techniques, such as ground penetrating radar and electrical resistivity tomography (ERT), and geomorphological analysis, in order to reconstruct the cave distribution and geometry in a urban context and, in particular, in historical centres. The interaction during recent centuries between human activity (caves excavation, birth and growth of an urban area) and the characters of the natural environment were the reasons of a progressive increase in hazard and vulnerability levels of several sites. The reconstruction of a detailed cave map distribution is the first step to define the anthropic and geomorphological hazard in urban areas, fundamental basis for planning and assessing the risk.
\end{abstract}

\section{Introduction}

This paper propose the use of near surface geophysics techniques, such as ground penetrating radar (GPR) and electrical resistivity tomography (ERT), in order to reconstruct an anthropic and/or natural cave system and its geometry in a urban context and, in particular, in historical centres. The geophysical methodological approach has been integrated with a geomorphological analysis finalized, to define the underground natural processes acting on study area.

There are a lot of historical Mediterranean sites founded on an original rupestrian settlement, of which often the new generations forgot the memory and new urban areas built on them covering any marks. The interaction during recent centuries between human activities (caves excavation, birth and growth of an urban area) and the characters of the natural en-

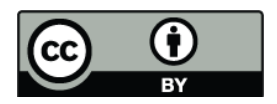

Correspondence to: M. Lazzari (m.lazzari@ibam.cnr.it ) vironment were the reasons of a progressive increase in hazard and vulnerability levels of several sites. A fundamental basis for planning and assessing the risk in a such situation is the reconstruction of a detailed cave map distribution in order to define the anthropic and geomorphological hazard in urban areas.

The integrated near surface geophysics and geomorphological techniques have been applied to the case study of Tursi hilltop town and its older part called Rabatana (Fig. 1), located in the south-western sector of the Basilicata (Southern Italy). Rabatana represents an interesting example how the interaction between natural and man-made environments can induct such a precious cultural heritage. The history of this settlement has always been deeply connected with the characteristics of the neighbouring environment and it seems possible that the first settlement was built by excavating the slopes of the sandy relief. It was a typical rupestrian settlement, where meteoric water was stored inside underground tank (cisterns) excavated on the slopes (Lazzari et al., 2006). During recent centuries, the increase in territory development by humans produced an increase in cave excavation in the Tursi-Rabatana urban area. To recognize and reconstruct the extremely complex system of excavated tunnels in the sandy layers, a geophysical investigation has been carried out, integrating the method of ERT (a multielectrode system with a Wenner-Schlumberger array layout) with the GPR (profiles were obtained using a SIR 2000-GSSI system equipped with two antennas of 400 and $200 \mathrm{MHz}$, connected by fibres-optic cables to the control unit) profiling.

Since 1973, this site was abandoned and all inhabitants were moved in a new urban site due to catastrophic landslides caused by intense rainfalls that occurred on January 1972 . Starting from 1974, the Rabatana has been completely abandoned. Recently, a renewed interest for this site has been developed to recover the historical center, removing the current constraint of total evacuation. However at present, the

Published by Copernicus Publications on behalf of the European Geosciences Union. 

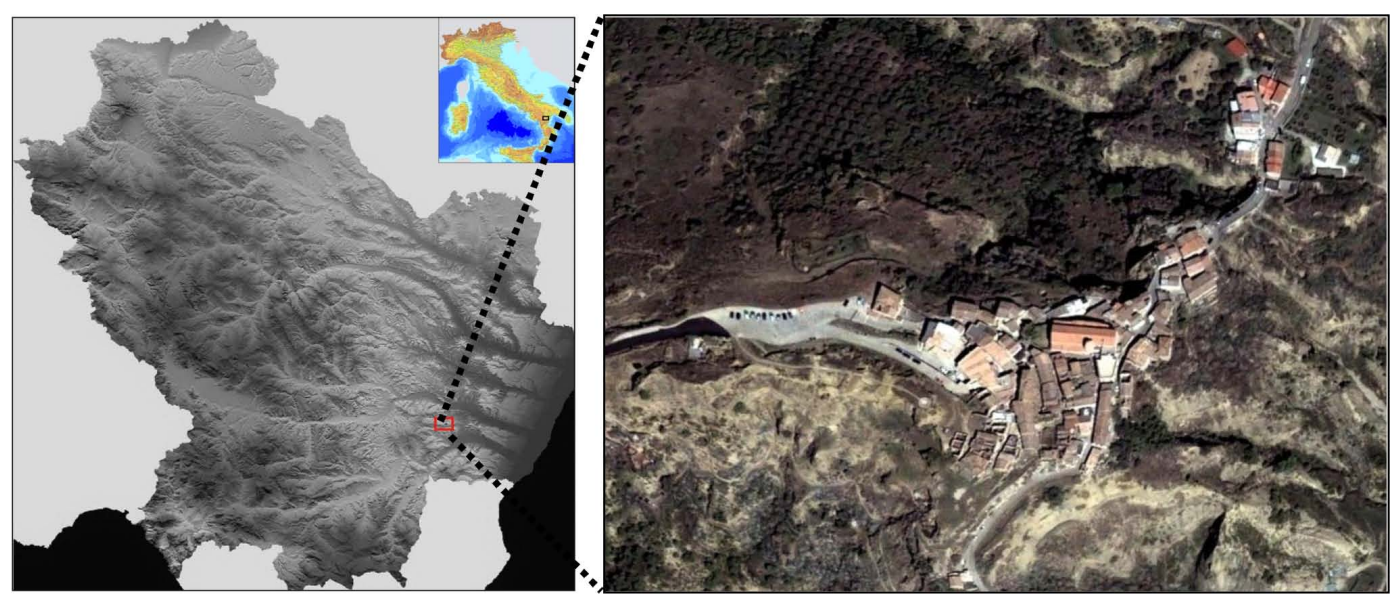

Fig. 1. Geographical location of the study area and satellite image of Rabatana site.

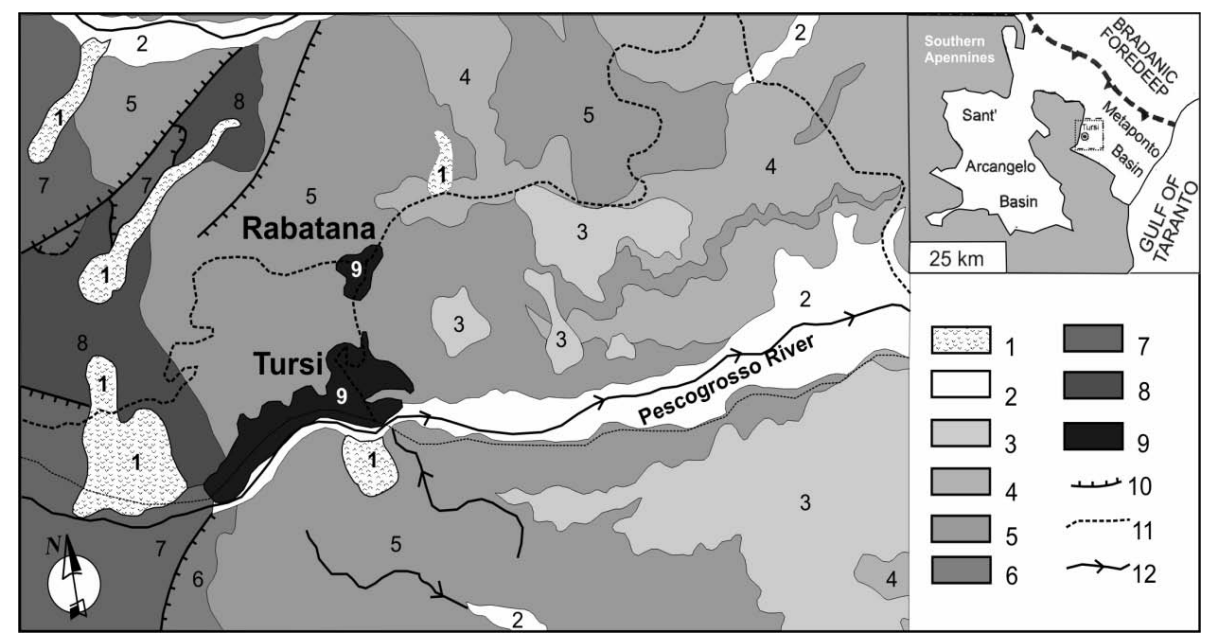

Fig. 2. Geological map of the Tursi-Rabatana site (after Lazzari et al., 2006). Legend: (1) Landslides; (2) Alluvial deposits; (3) Greyblue clays Formation; (4) Fluvial terraces; (5) Tursi Group (lower Pleistocene); (6) Pliocene deposits; (7) Varicolours clays Formation (Cretaceous-Oligocene); (8) Flysch of Serra Palazzo (Miocene); (9) built-up areas; (10) main faults; (11) main roads; (12) water source (perennial streams).

site is still characterized by a particular morphological history and environmental factors that generate widespread risk conditions for the inhabitants and built-up areas (Lazzari et al., 2008).

\section{Geological and geomorphological setting}

The study area is located along the outer outcropping front of the southern Apennines thrust belt, exactly on the outer margin of the Plio-Pleistocene Sant'Arcangelo basin (Fig. 2) interpreted by several authors as the largest and most recent onshore piggyback basin (Caldara et al., 1988; Casero et al., 1988; Hippolyte, 1992; Hippolite et al., 1994). This basin was filled by huge volumes of synsedimentary (Hippolite et al., 1994; Zavala and Mutti, 1996) siliciclastic deposits rang- ing from alluvial conglomerates in the west to marine shelf mudstones in the east. The main geological unit outcropping on the studied site is the Tursi Group (early-middle Pleistocene, Sabbie di Tursi Fm.), characterized by a total thickness of $500 \mathrm{~m}$ and composed of two sub-units corresponding to an alluvial fan and fan delta system. The lithology of the substratum (well-cemented sands, silt-clayey sands and subordinately sandy conglomerates) and rainfalls are the main factors to which the landscape evolution is linked. These represent the main determining elements for landslide triggering and linear erosion phenomena (Lazzari et al., 2006). In fact, morphological evolution of the sandy hillslopes on which Tursi town rises is characterized by very intense erosive phenomena such as landslides, deep gullies, rills, and piping, which affect the whole perimeter of urban settlements 


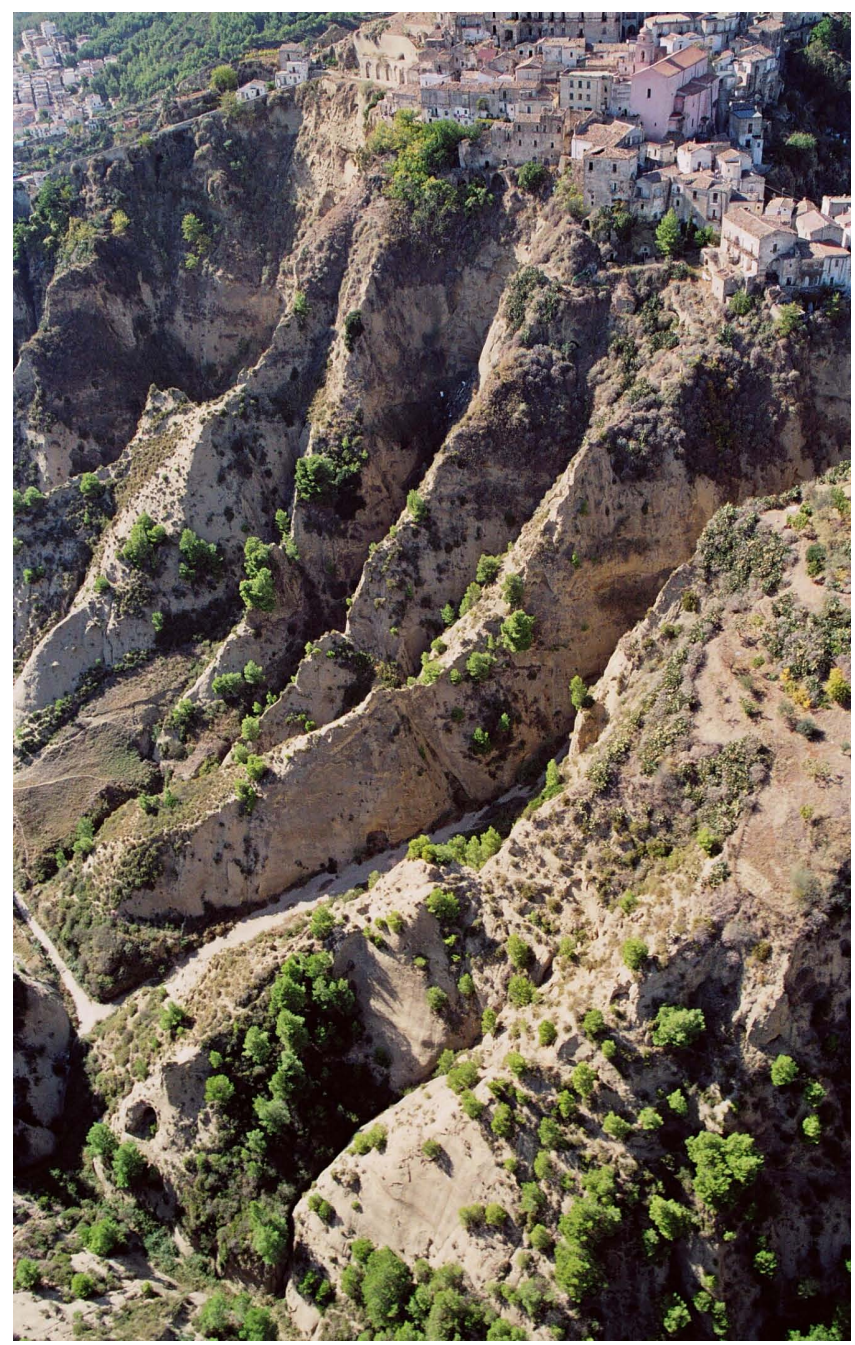

Fig. 3. Aerial view of Rabatana showing the deep gullies distributed around all the urban perimeter and due to intence erosional processes.

and threaten the conservation of these sites (Fig. 3). From the point of view of the process of physical degradation, the sandy facies are characterized by desiccation cracks to which the piping erosion and detachment blocks along the slopes are closely linked (Lazzari et al., 2006). In some cases large voids do not develop, but seepage erosion and running sand cause morphologically similar surface collapse phenomena (sinkholes). Outlets spreading can cause landslide phenomena (rockfall and toppling) along the steep sandyclayey slopes (Fig. 4).

The secular multilevel cave excavation, developed along several fronts beneath the urban area, accelerated the preexisting morphological processes acting on this site, favouring the water infiltration and subsurface erosional phenomena, characterized by widespread surface piping erosion of sandy bodies. Moreover, climate analysis carried out for the

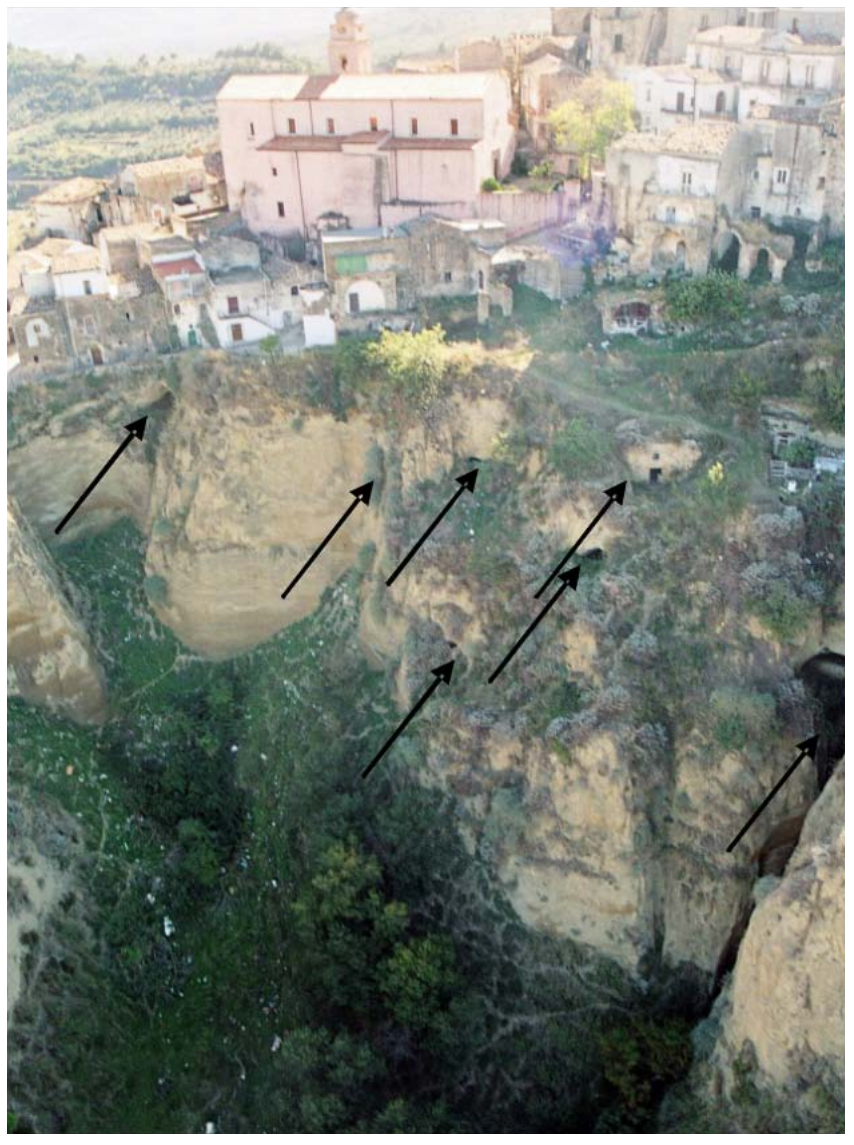

Fig. 4. Western sector of Rabatana characterized by large voids and caves (black arrows show the entries) located under the urban settlement.

last century showed an increasing trend in rainfall intensity over short durations, which also induced an increase in hazard conditions of the slopes.

\section{Hazard cave map reconstruction}

To analyze the anthropic hazard due to caves distribution, a cave map has been reconstructed (Fig. 5) through a field survey preliminary approach and then using geophysical methods.

The field survey permitted to evidence, for the Rabatana historical site, about 100 caves for which it is possible to see clear the entrances, while at least 300 other caves are located in Tursi urban area and surroundings. This survey excludes all the caves and cisterns not directly ispectionable, but well showed in geophysical data. 


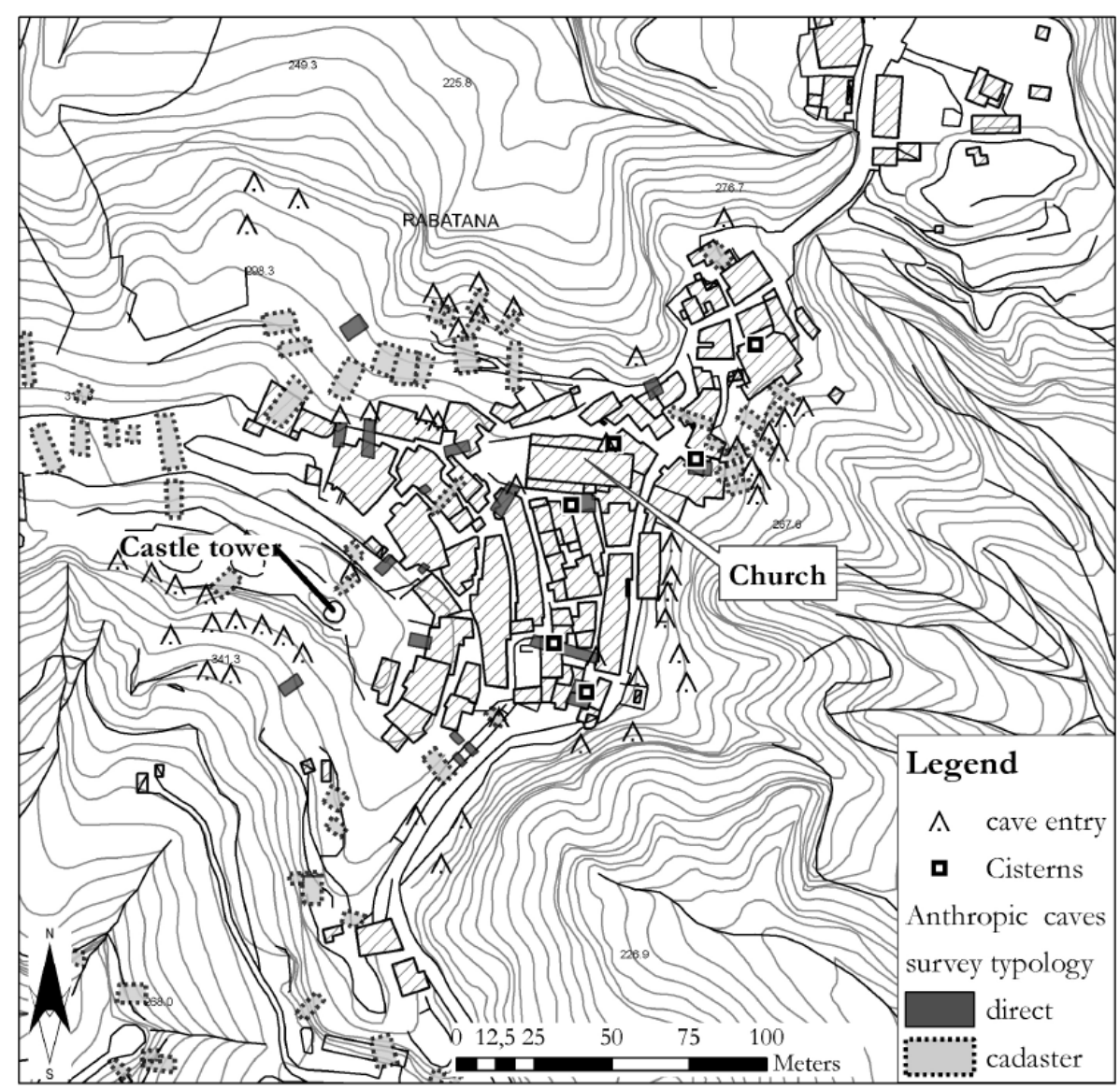

Fig. 5. Distribution of caves surveyed in Rabatana historical centre.

\subsection{Near surface geophysical approach}

Two integrated geophysical methods of Electrical Resistivity Tomography (ERT) with the GPR (Ground Penetrating Radar) profiling (Fig. 6) have been carried out in the Rabatana historical site, in order to reconstruct the extremely complex near-surface hypogeal environment excavated in the sandy layers.

\subsubsection{Electrical resistivity tomography technique}

ERT is an active geoelectrical prospecting technique used to obtain 2-D, 3-D and 4-D (with time) images of the subsurface electrical resistivity distribution. It has been applied for investigating areas of complex geology, such as volcanic and geothermal areas (Di Maio et al., 1998), seismotectonic structures (Caputo et al., 2003; Nguyen et al., 2005), and areas affected by hydrogeologic phenomena and environmental problems (Ogilvy et al., 1999; Lapenna et al., 2005; Soupios et al., 2007; Georgaki et al., 2007; Naudet et al., 2008). It has been also used to locate cavities in the subsoil (El-Qady et al., 2005; Gibson et al., 2007; Crawford et al., 2007; Mitrofan et al., 2008; Soupios et al., 2008).
Technically the ERT is obtained by using different multielectrode arrays, such as the dipole-dipole, Wenner, Schlumberger and Wenner-Schlumberger, the choice of which depends on the subsoil, the depth of investigation, the sensitivity to vertical and horizontal changes in the subsurface resistivity, the horizontal data coverage and the signal strength (Loke, 1999). The current is injected into the ground through a couple of electrodes, and the resulting potential differences are measured between another couple of electrodes at the surface. The mathematical combination between electric currents and voltage measurements provides the apparent resistivity values. Using the commercial software RES2DINV proposed by Loke and Barker (1996) the apparent resistivity values are inverted in true resistivity values. The inversion routine is based on the smoothness constrained leastsquares inversion implemented by using a quasi-Newton optimisation technique. The subsurface is divided into rectangular blocks, the number of which corresponds to the number of measurement points. The optimisation method adjusts the 2-D resistivity model trying to iteratively reduce the difference between the calculated and measured apparent resistivity values. The root-mean-squared (RMS) error provides a measurement of this difference. 


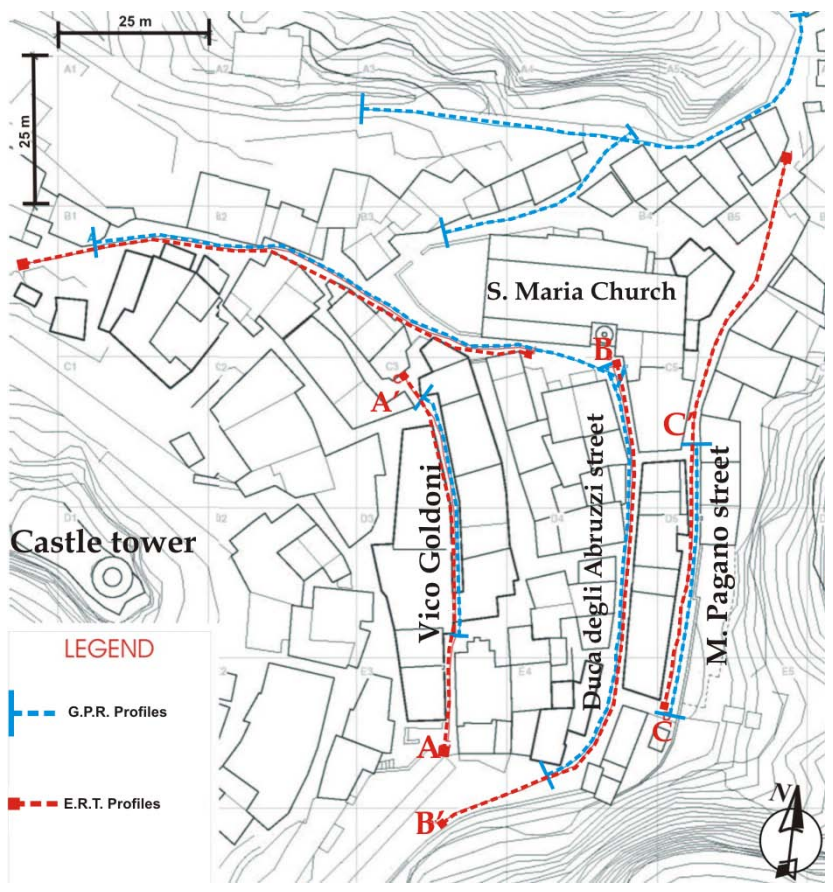

Fig. 6. Map of geophysical investigations carried out in historical centre of Rabatana site.

We applied this method in order to reconstruct the geological setting of the subsoil in the Rabatana site and to depict the geometric features of the cavities.

A georesistivitymeter Syscal R2, connected to a multielectrode system characterized by 32 electrodes and different electrode spacing, has been used in order to change the investigation depth and the spatial resolution.

The obtained tomographies are characterized by resistivity $(\rho)$ values varying in the range $5-900 \Omega \mathrm{m}$. The high resistivity values $(\rho>500 \Omega \mathrm{m})$ are correlated with the presence of empty caves in the first layers of the subsoil. Low resistivity values $(\rho<40 \Omega \mathrm{m})$ can be associated with terrain characterized by high water content.

In particular, the AA' ERT crossing Vico Goldoni street (Fig. 7) has been performed by using a $2 \mathrm{~m}$ electrode spacing and reaching an investigation depth of about $10 \mathrm{~m}$. It is characterized by a shallow resistive layer (about $2 \mathrm{~m}$ thick) with the presence of higher resistive cores (black circle in the figure), associated with the existence of caves. One of these is well visible at about $22 \mathrm{~m}$ from the origin of the profile. The ERT also shows the presence of some conductive cores related to zones of the subsoil characterized by water saturated sectors.

Different electrode spacing ( $3 \mathrm{~m}$ ) have been used for BB' and CC' ERT profiles, in which a clear high contrast value between the cave zones (800-900 $\Omega \mathrm{m}$ resistivity values) and deeper zones $(5-10 \Omega \mathrm{m}$ resistivity values) have been also measured. This last condition produced RMS error values higher than AA' ERT profile.
The BB' ERT, crossing Duca degli Abruzzi street close to the church, reaches an investigation depth of about $14 \mathrm{~m}$. It shows a highly resistive surface layer within which it is possible to distinguish different caves (black circles). Many of these have been inspected to confirm the results obtained by using the geoelectrical method. The deep part of the ERT is characterized by high conductive cores associated with the presence of water saturated zones in the subsoil.

Finally, the CC' ERT crossing Vico M. Pagano street (Fig. 7) has been carried out reaching an investigation depth of about $16 \mathrm{~m}$. In the southern sector, it is characterized by very high resistive material due to the presence of different caves (black circle) in the subsoil. Some of these caves are linked to each other, as well reported by the direct inspection. The central and northern parts of the ERT highlight conductive material correlated with the presence of terrain characterized by high water content.

\subsubsection{Ground penetrating radar technique}

Ground penetrating radar (GPR) is an electromagnetic pulse reflection method based on physical principles similar to those of reflection seismics. It is a geophysical technique for shallow investigations with high resolution which has undergone a rapid development during the last two decades (Blindow et al., 1987). There are several synonyms and acronyms for this method like EMR (electromagnetic reflection), SIR (subsurface interface radar), georadar, subsurface penetrating radar and soil radar.

The GPR has been used increasingly and accepted for geological, engineering, environmental (Tsokas et al., 1999; Stampolidis et al., 2003; Loperte et al., 2004) and archaeological science starting from the 1980s. In fact, it offers very high performances in terms of non invasivity, real time information and available spatial resolution thanks to the use of a easy and portable instrumentation able to perform measurements in an simple and fast way (Daniels, 1996; Lazzari et al., 2006).

The GPR works by emitting an electromagnetic (em) pulse, generated by a transmitter antenna, towards the surface of the ground or any other object, and records (thanks to the same antenna or another one that acts as a receiver) the amplitude and time delay of any secondary reflection coming from the subsurface structures that may represent anomalies in terms of conductivity $(\sigma)$ and/or (dielectric) permittivity $(\varepsilon)$ with respect to the host medium. The raw time-amplitude data (radargram) are usually displayed as a two-dimensional profile (B-scan) with the $X$-axis denoting the movement direction of the antenna and the $Y$-axis representing the twotravel-time (proportional to the depth).

A SIR 2000 Radar System matched to a monostatic antenna of $200 \mathrm{MHz}$ central frequency was used to accomplish the survey. The data were acquired in continuous mode. The acquisition time range was $110 \mathrm{~ns}$. 


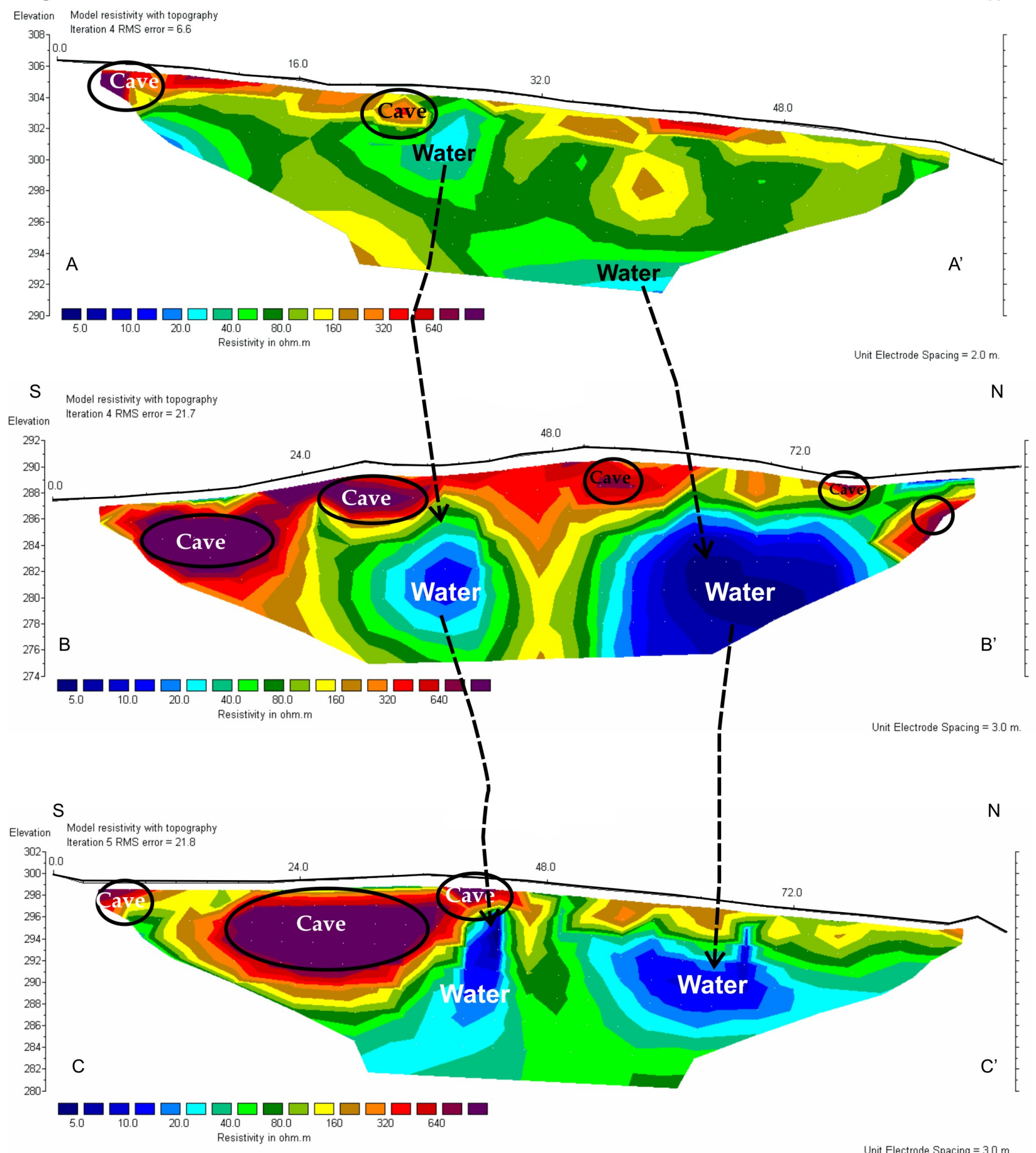

Fig. 7. Three main ERT carried out along the Vico Goldoni (A-A'), Duca degli Abruzzi (B-B') and M. Pagano (C-C') streets. The black arrows show the flow direction of water seepage along the underground sandy-clayey substratum from the castle tower (higher topographic point) to the steep slopes. Higher and lower resistivity cores, associated to caves and water seepage areas, respectively, are also well visible. 

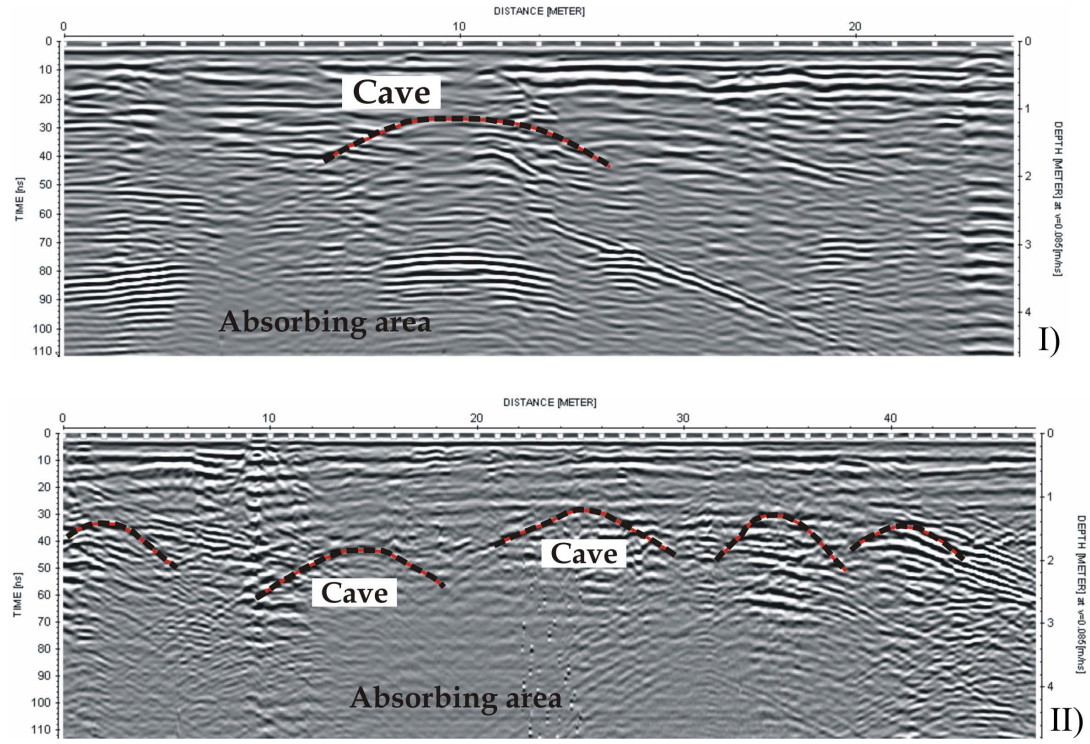

Fig. 8. Main representative radargrams carried out along Vico Goldoni (I) and M. Pagano (II) streets located at different topographic heights in Rabatana site.

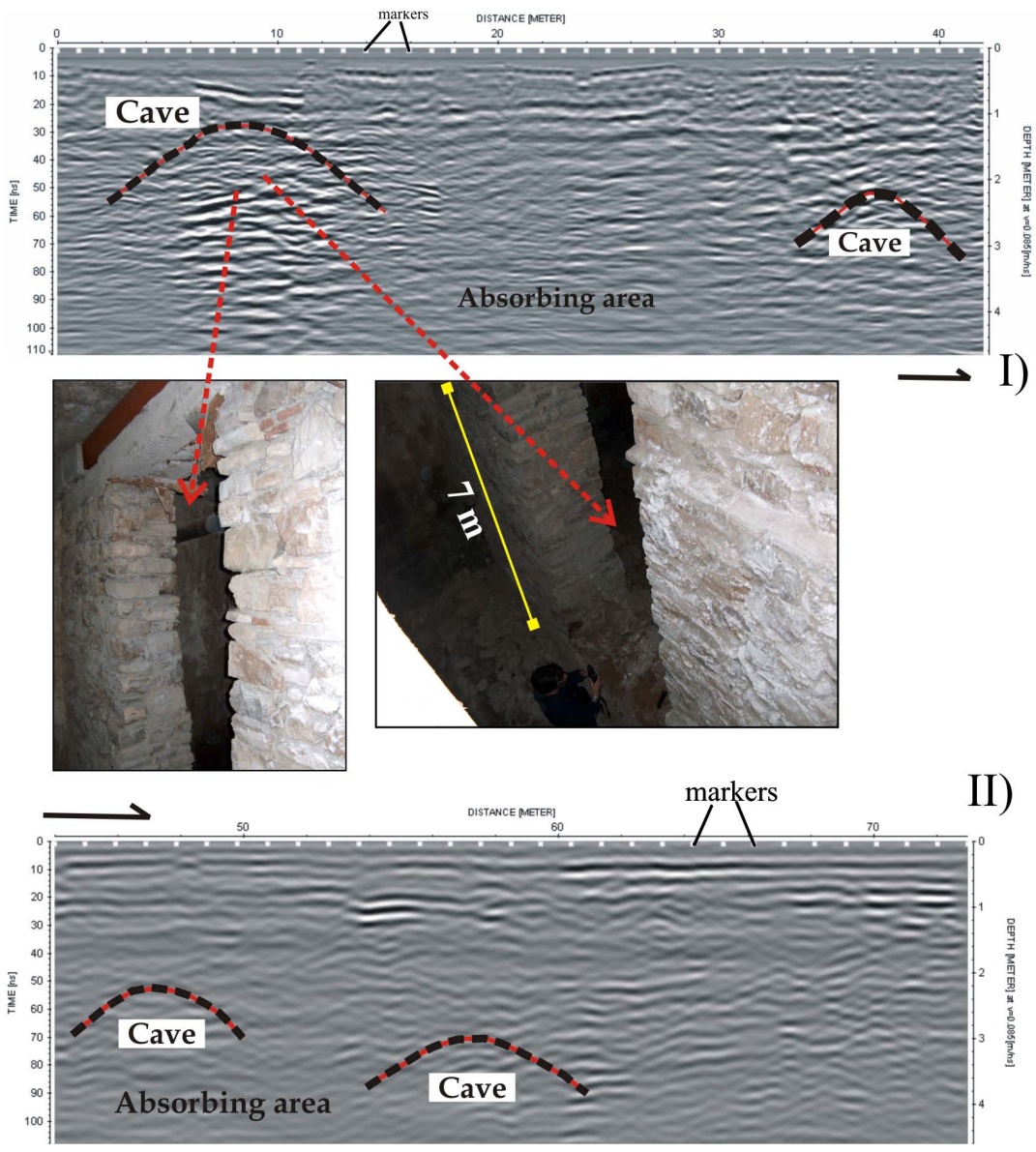

Fig. 9. Radargrams carried out along Duca degli Abruzzi street shows a very large cave with a vault $7 \mathrm{~m}$ high and perimetric stone walls (I). In this case the high risk level is due to the extremely reduced diaphragm between the empty cave and the overhanging Duca degli Abruzzi street. 

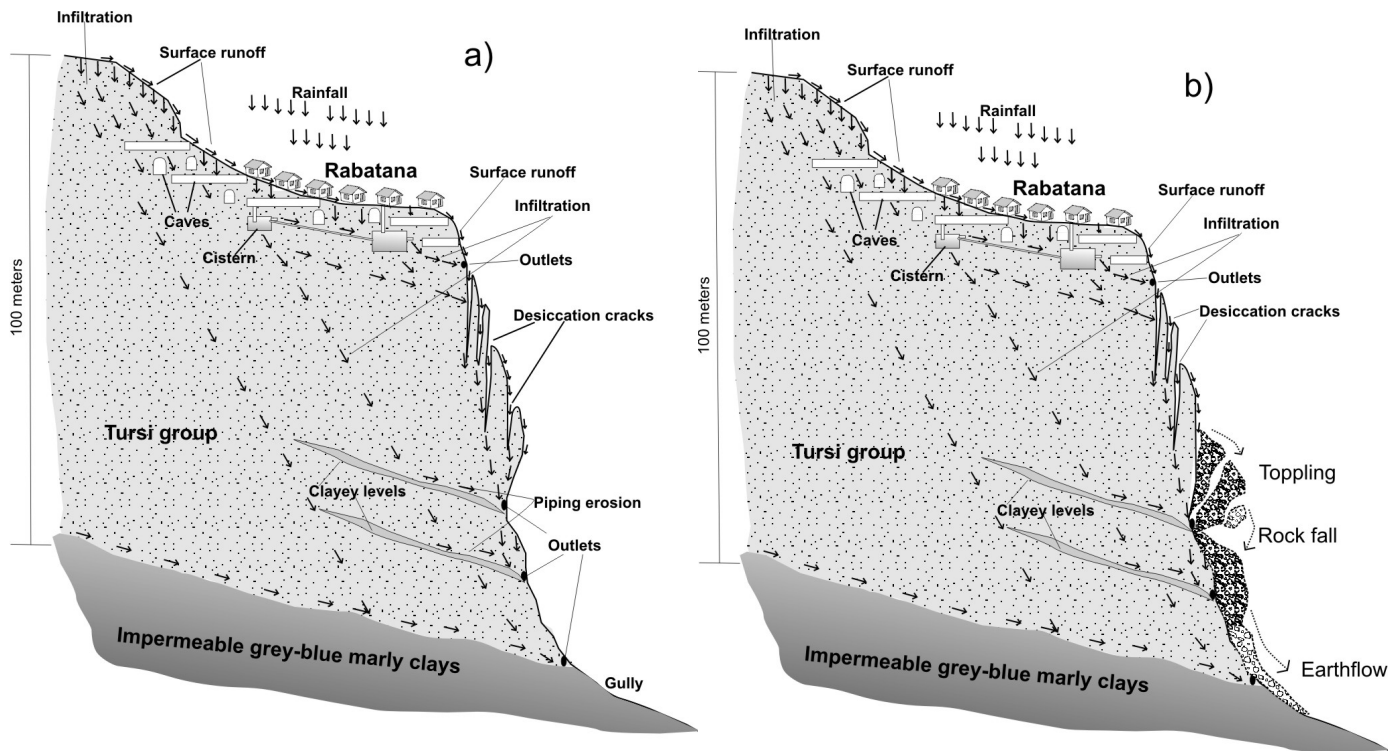

Fig. 10. Representative scheme of the evolution of the morphological processes acting on Rabatana slopes and subsurface. In (a) the predisposing elements to landslide and collapse phenomena are shown. The following morphological phase is shown in (b) where the main morphological effect is linked to the slope movements and cave collapses (after Lazzari et al., 2006).

Owing to the presence of several obstacles (main anthropization) within the village, here shows the main radargram acquired.

The survey was focused on three different roads. In total 50 GPR-profiles comprising more than $2.700 \mathrm{~m}$ of linear survey were made, of these the most relevant radar sections will be shown.

The GPR data set was analysed using the REFLEX- Win Version 5.0.5 program (Sandmeier software). Profile processing included sequential zero-time corrections, running average filter, exponential gain function, band-pass filter and plotting.

In particular, the GPR-section, carried out along Vico Goldoni street which is totally $24 \mathrm{~m}$ long (Fig. 8I), is characterized by hyperbolic anomalies, associated with the presence of caves, such as the one located between $7 \mathrm{~m}$ and $12 \mathrm{~m}$ from the origin of the profile. Furthermore, the lower part of GPR-section shows the presence of an absorbing area, probably related to the presence of soil characterized by high water content.

The Vico M. Pagano street GPR section, which is totally $47 \mathrm{~m}$ long (Fig. 8II), shows various hyperbolic reflectors that occur throughout the radargram. The bottom part shows the presence of a very high absorbing zone corresponding to the conductive zone of geoelectric surveys.

The radar section (Fig. 9I and II) carried out along Duca Degli Abruzzi road is $72 \mathrm{~m}$ long. The first part (Fig. 9I) is characterized by two hyperbolic reflectors, respectively between 6 and $10 \mathrm{~m}$ related to a very large cave unknown to the citizens, while in the central part there is an absorbing zone.
The second electromagnetic image (Fig. 9II) shows hyperbolic reflectors associated with the presence of caves in the subsoil both in the first and in the second part.

\section{Conclusions}

The integrated analysis of geophysical techniques and geomorphological field survey permitted to reconstruct a map of man made caves showing the interaction areas with historical buildings in which the collapse and sinkhole risk is higher. In particular, ERT furnished a further validation element to the morphoevolutive model proposed by Lazzari et al. (2006) for the Rabatana hilltop village (Fig. 10). In fact, observing all together the three ERTs (Fig. 7), carried out along profiles parallel to each other at different heights, it is possible to distinguish the geometrical development of the areas characterized by highest water content with two main conductive cores due to water seepage from the higher altitudes (where the sandy substratum outcrops directly and some ruins without roofs are also present) toward the lower, where wide moisture areas were generated along the outer slopes of Rabatana. In particular, it is well visible as the small conductive cores characterizing the AA' ERT increase their sizes in the BB' ERT and decrease sizes where the water goes out, close to the area where the CC' ERT has been performed.

Water seepage, distinguishable also during the summer time, determined an acceleration of underground erosional processes (piping) inducing an upward enlargement of cave vaults and sometimes their collapse. Due to general complexity of the study area and the impossibility to survey 
directly all caves, it is evident as the ERT and GPR techniques have been fundamental to interpreter the determining causes of collapses-triggering.

All the natural and anthropic conditions described above show as a deep knowledge of cave distribution and their geometry is the basis for a good urban planning to apply in historical site particularly vulnerable; it also shows as the integrated near surface geophysics techniques can powerfully contribute to acquire useful information to mitigate the anthropic risk and preserve the historical-monumental heritage.

Acknowledgements. We would like to thank the anonymous referees for the useful comments and suggestions to improve the manuscript.

Edited by: L. Eppelbaum, N. Masini, and F. Soldovieri Reviewed by: two anonymous referees

\section{References}

Blindow, N., Erzenginger, P., Pahls, H., Scholz, H., and Thyssen, F.: Continuous profiling of subsurface structures and groundwater surface by EMR methods in Southern Egypt. Berliner Geowiss. Abh. (A) 75.2, 575-627, 1987.

Caldara, M., Loiacono, F., Morlotti, E., Pieri, P., and Sabato, L.: I depositi pliopleistocenici della parte Nord del bacino di Sant'Arcangelo (Appennino lucano): caratteri geologici e paleoambientali, Mem. Soc. Geol. It., 41, 391-410, 1988.

Caputo, R., Piscitelli, S., Oliveto, A., Rizzo, E., and Lapenna, V.: High-resolution resistivity tomographies in Active Tectonic studies. Examples from the Tyrnavos Basin, Greece. J. Geodyn., 36, 19-35, 2003.

Crawford, N. C., Croft, L. A., Cesin, G. L., and Wilson, S.: Microgravity and Electrical Resistivity Techniques for Detection of Caves and Clandestine Tunnels, American Geophysical Union, Fall Meeting 2007, abstract \#NS21A-05, 2007.

Casero, P., Roure, F., Endignoux, L., Moretti, I., Muller, C., Sage, L., and Vially, R: Neogene geodynamic evolution of the southern Apennines, Mem. Soc. Geol. It., 41, 109-120, 1988.

Daniels, D. J.: Surface-penetrating Radar, Institution of Electrical Engineers Radar Series, ERA Technology, ISBN 0-85296-862, No. 6, London, UK, 1996.

Di Maio, R., Mauriello, P., Patella, D., Petrillo, Z., Piscitelli, S., and Siniscalchi, A.: Electric and electromagnetic outline of the Mount Somma-Vesuvius structural setting, J. Volcanol. Geotherm. Res., 82, 219-238, 1998.

El-Qady, G., Hafez, M., Abdalla, M., and Ushijima, K.,: Imaging subsurface cavities using geoelectric tomography and groundpenetrating radar, J. Cave Karst. Stud., 67(3), 174-181, 2005.

Georgaki I., Soupios, P., Sakkas, N., Ververidis, P., Trandas, E., Vallianatos, F., and Manios T.: Evaluating the Use of Electrical Resistivity Imaging Technique For Improving $\mathrm{CH}_{4}$ and $\mathrm{CO}_{2}$ Emission Rate Estimations in Landfills, Sci. Total Environ., 389, 522-531, 2007.

Gibson, P. J., Lyle, P., and George, D. M.: Application of resistivity and magnetometry geophysical techniques for near-surface investigations in karstic terranes in Ireland, J. Cave Karst. Stud., 66(2), 35-38, 2007.
Lapenna, V., Lorenzo, P., Perrone, A., Piscitelli, S., Rizzo, E., and Sdao, F.: Case History 2-D electrical resistivity imaging of some complex landslides in the Lucanian Apennine chain, southern Italy, Geophysics, 70(3), B11-B18, 2005.

Lazzari M., Danese M., and Masini N.: GIS applications for recovery and management of historical-architectonic heritage: case study of Tursi-Rabatana medieval site (Southern Italy). Proceedings of 1st EARSeL Workshop, Rome 30 September-4 October, 2008, on 1"Advances in Remote Sensing for Archaeology and Cultural Heritage Management", Aracne Editore, Roma, 347350, 2008.

Lazzari, M., Geraldi, E., Lapenna, A., and Loperte, A.: Natural hazards vs. human impact: an approach in geomorphological risk assessment on the Tursi historical site, Southern Italy, Landslides, 3(4), 275-287, 2006.

Loke, M. H.: RES2DINV ver. 3.42, Geoelectrical Imaging 2-D \& 3-D, User Manual, 1999.

Loke, M. H. and Barker, R. D.: Rapid least-squares inversion of apparent resistivity pseudosections by a quasi-Newton method, Geophys. Prospect., 44, 131-152, 1996.

Loperte, A., Cristallo, F., Lapenna, V., Bavusi, M., Piscitelli, S., and Rizzo, E.: GPR and Electrical tomography survey to detect cavities in the urban area of Matera (southern Italy). Progress in Electromagnetic Research Symposium, 28-31 March, Pisa, Italy, 2004.

Hippolyte J. C.: Tectonique de l'Apennin méridional: structures et paléocontraintes d'un prisme d'accrétion continental, Unpubl. PhD. Thesis, Université P. et M. Curies, Paris, 1992.

Hippolyte, J. C., Angelier, J., Roure, F., and Casero, P.: Piggyback basin development and thrust belt evolution: structural and paleostress analysis of Plio-Quaternary basin in the southern Apennines, J. Struct. Geol., 16, 159-173, 1994.

Mitrofan, H., Povară I., and Mafteiu, M.: Geoelectrical investigations by means of resistivity methods in karst areas in Romania, Environ. Geol., 55(2), 405-413, doi:10.1007/s00254-007-0986$1,2008$.

Naudet, V., Lazzari, M., Perrone, A., Loperte, A., Piscitelli, S., and Lapenna, V.: Integrated geophysical and geomorphological approach to investigate the snowmelt-triggered landslide of Bosco Piccolo village (Basilicata, southern Italy), Eng. Geol., 98, 156167, 2008.

Nguyen, F., Garambois, S., Jongmans, D., Pirard, E., and Locke, M.: Image processing of 2-D resistivity data to locate precisely faults, J. Appl. Geophys. 57, 260-277, 2005.

Ogilvy, R., Meldrum, P., and Chambers, J.: Imaging of industrial waste deposits and buried quarry geometry by 3 -D resistivity tomography, Eur. J. Environ. Eng. Geophys., 3, 103-113, 1999.

Soupios, P., Papadopoulos, N., Papadopoulos, I., Kouli, M., Vallianatos, F., Sarris, A., and Manios, T.: Application of Integrated Methods in Mapping Waste Disposal Areas, Environ. Geol., 53(3), 661-675, 2007.

Soupios, P., Loupasakis, C., and Vallianatos, F.: Reconstructing former urban environments by combining geophysical electrical methods and geotechnical engineering - an example from Chania, Greece, J. Geophys. Eng., 186-194, 2008.

Stampolidis, A., Soupios, P., Tsokas, G. N., and Vallianatos F.: Detection of Leaks in Buried Plastic Water Distribution Pipes in Urban Places Using GPR - A Case Study, edited by: Yarovoy, A., International Research Centre for Telecommunications- 
transmissions and Radar, IRCTR, ISBN 90-76928-04-5, IEEE catalog number 03EX680, 2003.

Tsokas, G., Soupios P., Tsourlos, P., Vargemezis, G., Savvaidis, A., Paliadeli-Saatsoglou, C., and Drougou, S.: Geophysical investigations in the area between Eukleia's temple and the theater in ancient Aegae (Verghina) using various methods, Physics in Culture, edited by: Paraskevopoulos, K., An Aristotle University Publication ISBN 960-243-573-9, 1999.
Zavala, C. and Mutti, E.: Stratigraphy of the Plio-Pleistocene Sant'Arcangelo basin, Basilicata, Italy, in: Proceedings of Riunione annuale del Gruppo Informale di Sedimentologia, Catania 10-14 ottobre 1996, 279-282, 1996. 